\title{
IMPLEMENTASI MODEL PEMBELAJARAN INTEGRATED PADA PERKULIAHAN PENDIDIKAN ILMU SOSIAL DI FKIP UM METRO
}

\author{
Bobi Hidayat \& Kuswono \\ Staf Pengajar Universitas Muhammadiyah Metro
}

\begin{abstract}
Abstrak: Penelitian ini merupakan penelitian tindakan kelas yang termasuk kedalam penelitian kualitatif (kualitative research). Penelitian ini dilakukan pada mahasiswa program studi pendidikan sejarah yang bertujuan untuk memperbaiki kualitas pembelajaran dengan menerapkan model pembelajaran integrated pada mata kuliah pendidikan ilmu sosial. Penelitian dilakukan berawal dari beberapa permasalahan yang ditemukan oleh peneliti yang sekaligus dosen pengajar yaitu kualitas pembelajaran yang kurang baik. Hal ini ditunjukkan dengan rendahnya aktivitas dan prestasi belajar mahasiswa.

Teknik pengumpulan data yang digunakan dalam penelitian ini adalah dengan cara pengamatan atau observasi, dokumentasi, wawancara, foto, dan tes. Langkah-langkah penelitian yang diambil adalah sesuai dengan langkah-langkah dalam penelitian tindakan kelas yaitu perencanaan (planning), pelaksanaan (acting), observasi (observing), dan refleksi (reflecting). Selanjutnya data yang diperoleh dianalisis dengan menggunakan pendekatan deskriptif analitik yang bertujuan untuk mencari gambaran alamiah dari temuan penelitian dan divalidasi dengan menggunakan teknik triangulasi.

Hasil penelitian menunjukkan bahwa penerapan model pembelajaran integrated pada mata kuliah pendidikan ilmu sosial mampu memperbaiki aktivitas dan dapat meningkatkan prestasi belajar mahasiswa.
\end{abstract}

Keywords : Model Pembelajaran Integrated, Aktivitas, dan Prestasi Belajar

\section{Pendahuluan}

Pendidikan ilmu sosial merupakan salah satu bidang ilmu pengetahuan yang harus diberikan kepada mahasiswa terutama mahasiswa yang mengambil jurusan pendidikan ilmu pengetahuan sosial. Orientasi diberikanya mata kuliah ini adalah untuk membekali dan mendukung mahasiswa dalam menjalankan tugasnya menjadi seorang guru yang profesional. Pendidikan ilmu sosial tidak hanya diberikan kepada mahasisawa yang mengambil jurusan pendidikan ilmu sosial, akan tetapi mahasiwa yang mengambil jurusan pendidikan sosiologi, ekonomi, sejarah, geografi yang merupakan bagian dari pendidikan ilmu sosial lainya juga diberikan.

Hal ini juga dilakukan oleh Universitas Muhammadiyah Metro. Universitas Muhammadiyah Metro adalah salah satu Universitas yang memiliki jurusan ilmu pengetahuan sosial yang salah satunya adalah program studi pendidikan sejarah. Program studi ini memiliki mata kuliah pendidikan ilmu sosial. Dimana salah satu pembahasanya adalah mengenai pendidikan ilmu sosial yang dipelajari di sekolah menengah pertama yang biasa disebut dengan pendidikan ilmu pengetahuan sosial (IPS). Materi pendidikan ilmu pengetahuan sosial (IPS) di sekolah menengah petama 
terdiri dari meteri sejarah, ekonomi, sosiologi, dan geografi yang merupakan bagian dari keilmuan pendidikan ilmu sosial. Hal ini sesuai yang diungkapkan oleh Sapriya (2009:200) Pada jenjang SMP/MTs mata pelajaran IPS memuat materi geografi, sejarah, sosiologi, dan ekonomi. Dalam mempelajarinya adalah dengan cara terpadu/terintegrasi antar keempat bidang ilmu tersebut. Sehingga mahasiswa dari program studi pendidikan sejarah sangat perlu untuk mengetahui bagaimana pembelajaran pendidikan IPS di SMP.

Selain pentingya mahasiswa mempelajari materi pendidikan ilmu pengetahuan sosial di sekolah menengah pertama, peneliti yang sekaligus dosen pengampu mata kuliah pendidikan ilmu sosial kerap kali menemukan proses pembelajaran pendidikan ilmu sosial yang masih kurang menarik. Hasil wawancara sebelumnya juga menunjukkan mahasiswa merasa jenuh dengan proses pembelajaran yang diterapkan sebelumnya, hal ini ditunjukkan dengan rendahnya prestasi belajar mahasiswa. Hal lain yang juga menunjukkan kejenuhan mahasiswa dalam belajar adalah mahasiswa cenderung diam dan jarang bertanya, ditemukan juga mahasiswa yang ngobrol bahkan ngantuk saat proses pembelajaran sedang berlangsung. Sehingga hal ini berdampak pada rendahnya aktivitas belajar mahasiswa, sehingga tujuan pembelajaran yang diinginkan belum sepenuhnya tercapai.

Permasalahan lain yang ditemukan dilapangan oleh dosen pengajar yang pernah juga menjadi Dosen Pembimbing Lapangan ketika mahasiswa mengikuti Program Pengalaman Lapangan (PPL) adalah Mahasiswa yang mengikuti PPL mengalami kesulitan dalam mengajar yang tidak sesuai dengan bidangnya akan tetapi hal itu sesuai dengan kurikulum pembelajaran ditingkat sekolah. Kurikulum ditingkat sekolah khususnya kurikulum sekolah menengah pertama (SMP) memadukan materi pendidikan sejarah, ekonomi, sosiologi, dan geografi menjadi mata pelajaran IPS terpadu, sehingga mahasiswa yang berasal dari program studi pendidikan sejarah mengalami kesulitan dalam menyampaikan materi ekonomi, sosiologi, atau geografi. Sehingga diperlukan pembelajaran dan pemahaman berkaitan dengan muatan materi pendidikan Ilmu Pengetahuan Sosial kepada mahasiswa program studi pendidikan sejarah, agar mereka mampu dan memiliki bekal ketika mereka melaksanakan program pengalaman lapangan (PPL) terutama yang ditempatkan di sekolah menengah pertama (SMP).

Berdasarkan beberapa permasalahan di atas, maka perlu untuk melakukan perbaikan dalam proses pembelajaran dengan memvariasikan model pembelajaran. Model 
pembelajaran yang akan digunakan adalah model pembelajaran integrated. Model pembelajaran integrated adalah model pembelajaran yang memadukan beberapa materi pelajaran yang berasal dari berbagai bidang ilmu. Peneliti mengambil model pembelajaran ini karena dirasa sesuai dengan karakteristik pembelajaran ilmu pengetahuan sosial disekolah menengah pertama.

\section{Metode Penelitian}

Penelitian ini adalah penelitian tindakan kelas. Penelitian tindakan kelas (classroom action research) merupakan bentuk penelitian yang bersifat reflektif dengan melakukan tindakan-tindakan tertentu agar dapat memperbaiki dan/atau meningkatkan praktik-praktik pembelajaran di kelas secara lebih profesional (Sukidin, 2008:28). Jadi penelitian ini merupakan penelitian tindakan kelas yang bersifat reflektif untuk meningkatkan kualitas pembelajaran agar lebih optimal.

Prosedur penelitian yang digunakan adalah prosedur dalam penelitian tindakan kelas. Prosedur PTK adalah suatu tahapan penelitian mulai dari perencaan atau persiapan tindakan (planning), pelaksanaan tindakan (acting), observasi (obseving) dan refleksi (reflecting) yang dilakukan secara berulang-ulang sampai titik jenuh atau ditemukanya model tidakan yang paling tepat dalam mengatasi masalah yang ditemukan di sekolah atau di kelas atau prestasi belajar siswa sudah mencapai nilai yang diinginkan sesuia dengan ketentuan. Hal itu dapat dilihat pada gambar berikut ini.

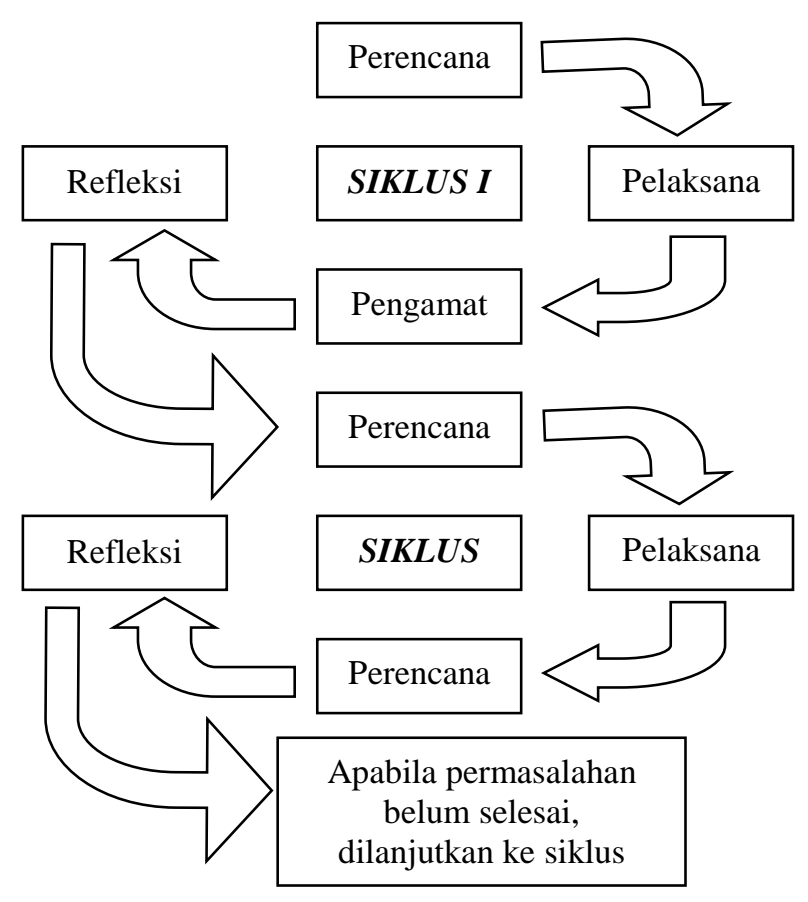

Teknik pengumpulan data yang digunakan antara lain : 1) Observasi digunakan untuk mengumpulkan data tentang aktivitas belajar mahasiswa. Observasi dilakukan berdasarkan panduan observasi yang sudah dibuat. 2) Dokumentasi dalam penelitian ini digunakan untuk mengumpulkan data berupa catatan dari hasil observasi serta data-data lain yang berupa tulisan-tulisan yang mendukung penelitian ini. 3) Wawancara dalam penelitian ini digunakan untuk mengetahui sejauh mana pelaksanaan tindakan yang telah dilakukan oleh dosen pengajar. Selanjutnya hasil wawancara digunakan untuk menentukan tindakan apa 
yang akan diambil selanjutnya. 4) Foto digunakan oleh peneliti adalah untuk meyakinkan bahwa data yang diperoleh atau terkumpul dalam penelitian lebih jelas, dan data tersebut benar adanya. Peneliti menggunakan kamera digital dalam merekam proses pembelajaran pada penelitian yang dilakukan. 5) Tes digunakan untuk mengetahui sejauh mana kemampuan mahasiswa setelah diberikan tindakan melalui penerapan model pembelajaran integrated. Tes digunakan untuk mengetahui sejauh mana prestasi belajar mahasiswa.

Selain metode pengumpul data, data perlu dilakukan validasi. Pada penelitian ini, validasi data akhir yang digunakan adalah Triangulasi. Triangulasi adalah memeriksa kebenaran hipotesis, konstruk atau analisis dari si peneliti dengan membandingkan hasil dari mitra peneliti. Triangulasi dilakukan berdasarkan tiga sudut pandang dosen sebagai peneliti, sudut pandang mahasiswa dan sudut pandang mitra peneliti yang melakukan pengamatan atau observasi dalam pembelajaran di kelas (Kunandar, 2008:107).

Indikator keberhasilan penelitian yang digunakan dalam penelitian ini adalah apabila terjadi peningkatan pada aktivitas dan hasil balajar mahasiswa. Yang menjadi patokan adalah proses pembelajaran sebelumnya, dan hasil refleksi dari setiap siklus pelaksanaan pembelajaran. Dengan mempertimbangkan hal itu, maka akan dapat ditentukan tingkat keberhasilan penelitian dan ada tidaknya tindakan pembelajaran selanjutnya.

\section{Pembahasan Hasil Penelitian}

Tabel 1. Aktivitas Belajar Mahasiswa siklus 1 dan 2

\begin{tabular}{|c|c|c|c|c|}
\hline \multirow[t]{2}{*}{$\begin{array}{l}\mathbf{N} \\
\mathbf{0}\end{array}$} & \multirow[t]{2}{*}{ Kriteria } & \multicolumn{2}{|c|}{$\begin{array}{c}\text { Jumlah } \\
\text { Mahasiswa/Persenta } \\
\text { se }\end{array}$} & \multirow[t]{2}{*}{ Ket } \\
\hline & & Siklus 1 & Siklus 2 & \\
\hline 1 & $\begin{array}{l}\text { Sangat } \\
\text { Rendah } \\
(\mathrm{SR})\end{array}$ & $0 / 00$ & $0 / 00$ & Tetap \\
\hline 2 & $\begin{array}{l}\text { Rendah } \\
\text { (R) }\end{array}$ & $14 / 40,00$ & $0 / 00$ & Menurun \\
\hline 3 & $\begin{array}{l}\text { Sedang } \\
\text { (S) }\end{array}$ & $11 / 31,43$ & $15 / 42,86$ & Meningkat \\
\hline 4 & $\begin{array}{l}\text { Tinggi } \\
\text { (T) }\end{array}$ & $10 / 28,57$ & $13 / 37,14$ & Meningkat \\
\hline 5 & $\begin{array}{l}\text { Sangat } \\
\text { Tinggi } \\
\text { (ST) }\end{array}$ & $0 / 00$ & $7 / 20,00$ & Meningkat \\
\hline \multicolumn{2}{|c|}{ Jumlah } & $35 / 100 \%$ & $35 / 100 \%$ & - \\
\hline
\end{tabular}

Sumber : Hasil Penelitian Aktivitas Belajar

Mahasiswa Siklus 1 dan 2

Tabel 2. Prestasi Belajar Mahasiswa siklus 1 dan 2

\begin{tabular}{|c|c|c|c|c|}
\hline \multirow[t]{2}{*}{$\begin{array}{l}\mathbf{N} \\
\mathbf{o}\end{array}$} & \multirow[t]{2}{*}{$\begin{array}{c}\text { Rentan } \\
\text { Nilai }\end{array}$} & \multicolumn{2}{|c|}{$\begin{array}{c}\text { Jumlah } \\
\text { Mahasiswa/Persentas } \\
\text { e } \\
\end{array}$} & \multirow[t]{2}{*}{ Ket } \\
\hline & & Siklus 1 & Siklus 2 & \\
\hline 1 & $1-20$ & $0 / 00$ & $0 / 00$ & Tetap \\
\hline 2 & $21-40$ & $2 / 5,71$ & $0 / 00$ & Menurun \\
\hline 3 & $41-60$ & $14 / 40,00$ & $0 / 00$ & Menurun \\
\hline 4 & $61-80$ & $15 / 42,86$ & $14 / 40,00$ & Menurun \\
\hline 5 & $81-100$ & $4 / 11,43$ & $21 / 60,00$ & Meningkat \\
\hline \multicolumn{2}{|c|}{ Jumlah } & $35 / 100 \%$ & $35 / 100 \%$ & - \\
\hline
\end{tabular}

Sumber : Hasil Penelitian Prestasi Belajar

Mahasiswa Siklus 1 dan 2

Berdasarkan tabel 1 tentang aktivitas belajar mahasiswa, dapat dilihat bahwa terdapat 
peningkatan antara siklus pertama dan kedua. Hal ini menunjukkan terdapat perbaikan proses pembelajaran pada siklus 2. Aktivitas belajar mahasiswa pada kisaran sangat rendah tetap tidak ada, sedangkan pada kisaran rendah mengalami penurunan hingga 0 , bahkan terdapat mahasiswa yang mencapai aktivitas belajar pada kisaran sangat tinggi yaitu sebanyak 7 mahasiswa pada proses pembelajaran siklus 2. Aktivitas belajar mahasiswa pada siklus 2 menunjukkan peningkatan yang baik sehingga berdasarkan hasil diskusi dengan dosen mitra dapat diperoleh bahwa pada penelitian aktivitas belajar mahasiswa pada siklus 2 dapat dikatakan sudah baik.

Sedangkan pada prestasi belajar mahasiswa, berdasarkan tabel 2 telah menunjukkan prestasi belajar yang memuaskan. Prestasi belajar mahasiswa pada siklus 2 tidak ada yang berada dibawah 60 , semua hasil belajar yang diperoleh mahasiswa diatas 60 . Melihat hasil penelitian tentang prestasi belajar mahasiswa pada siklus 2 disimpulkan bahwa penelitian prestasi belajar mahasiswa sudah dapat dikatakan berhasil.

Melihat data tabel 1 dan 2 yang merupakan data hasil dari proses pembelajaran menggunakan model pembelaaran integrated, menunjukkan bahwa penerapan model pembejaran ini dapat meningkatkan aktivitas belajar mahasiswa. Peningkatan aktivitas mahasiswa selain didukung oleh kerja secara berkelompok, materi dan lembar kerja mahasiswa juga menuntut mahasiswa untuk melakukan aktivitas yang lebih. Mereka saling mencari dan memberi informasi terkait tugas yang diberikan. Memahami dan menerapkan konsep integrated yang dipandu menggunakan bahan bacaan dan lembar kerja mahasiswa menuntut kerjasama dan tentu aktivitas berupa bertanya, menjawab berargumen dan aktivitas-aktivitas belajar lainya dapat secara alamiah dilakukan oleh mahasiswa.

Selain aktivitas belajar yang mengalami perbaikan, prestasi belajar mahasiswa juga mengalami perbaikan dan peningkatan. Dengan aktivitas belajar yang tinggi, mahasiswa akan lebih menguasai materi pembelajaran sehingga ketika mengerjakan tes sebagai ukuran penguasaan materi, mahasiswa dapat menjawab dengan baik. Model pembelajaran integrated dari hasil penelitian ini cocok digunakan untuk menyampaikan materi tentang pendidikan IPS di SMP. Dimana materi pendidikan IPS di SMP memuat materi dari konsep geografi, sosiologi, ekonomi dan sejarah. Sehingga dalam mempelajarinya model pembelajaran ini mampu mengintegrasikan konsep tersebut.

Dari keseluruhan proses penelitian dan hasil diskusi dengan dosen mitra serta berkomunikasi dengan mahasiswa melalui 
wawancara tentang proses pembelajaran yang telah dilaksanakan pada siklus dua, maka proses pembelajaran tidak dilanjutkan pada siklus selanjutnya. Hasil wawancara menunjukkan bahwa proses pembelajaran yang dilakukan pada siklus dua sudah dapat meningkatkan aktivitas belajar mahasiswa dan dapat memperbaiki prestasi belajar mahasiswa.

\section{Simpulan}

Berdasarkan hasil penelitian mengenai implementasi model pembelajaran integrated pada perkuliahan pendidikan ilmu sosial pokok bahasan pendidikan ilmu pengetahuan sosial Sekolah Menengah Pertama (SMP) dapat diambil simpulan bahwa implementasi model pembelajaran integrated pada perkuliahan pendidikan ilmu sosial pokok bahasan pendidikan ilmu pengetahuan sosial Sekolah Menengah Pertama (SMP) terbukti dapat memperbaiki aktivitas dan meningkatkan prestasi belajar mahasiswa

\section{Saran}

1. Bagi Mahasiswa

Bagi mahasiswa disarankan untuk aktif dan kreatif membantu serta mendukung dosen dalam menggunakan model pembelajaran yang bervariasi guna memperbaiki aktivitas dan meningkatkan prestasi belajar mahasiswa.
2. Bagi Dosen Pengajar

Implementasi model pembelajaran integrated pada perkuliahan pendidikan ilmu sosial dirasa cocok untuk menyampaikan pokok bahasan pendidikan ilmu pengetahuan sosial Sekolah Menengah Pertama (SMP) sehingga dosen lain dapat menggunakan model pembelajaran ini dalam menyampaikan materi tersebut.

3. Bagi Program Studi Pendidikan Sejarah Bagi program studi pendidikan sejarah disarankan untuk dapat mendukung dosen dan mengarahkan dosen untuk dapat menggunakan model pembelajaran yang bervariasi guna memperbaiki dan meningkatkan prestasi belajar mahasiswa. 


\section{Daftar Referensi}

Kunandar. 2008. Langkah Mudah

Penelitian Tindakan Kelas sebagai Pengembangan Profesi Guru. Jakarta.PT Rajagrafindo Persada.

Sapriya. 2009. Pendidikan IPS Konsep dan

Pembelajaran. Bandung. PT

Remaja

Rosdakarya

Somantri, M. Numan. 2001. Menggagas Pembaharuan Pendidikan IPS. PT Remaja Rosdakarya. Bandung

Sukidin. 2008. Manajemen Penelitian

Tindakan kelas. Insan Cendikia.

Surabaya 